\title{
Evaluation of designed IS711 primers and universal primers of B4 and B5 for detection of Brucella spp. in clinical samples
}

\section{Pedram Heidari}

Islamic Azad University Tehran North Branch

Mitra Salehi

Islamic Azad University Tehran North Branch

Abbas Akhavan Sepahi

Islamic Azad University Tehran North Branch

Mohamad Reza Razavi ( $\nabla$ mrrazavi@pasteur.ac.ir)

Pasteur Institute of Iran https://orcid.org/0000-0002-2204-6267

Research article

Keywords: PCR, Brucella melitensis, Human brucellosis, Serum samples

Posted Date: August 14th, 2019

DOI: https://doi.org/10.21203/rs.2.12863/v1

License: (a) (i) This work is licensed under a Creative Commons Attribution 4.0 International License.

Read Full License 


\section{Abstract}

Background Brucellosis as a global concern is a zoonotic infectious disease which affects a wide range of individual in developing countries. A confirmed diagnosis is required to isolate the bacterial agent from clinical specimens like blood, bone marrow, CSF or tissues. Microbiological, serological and molecular approaches are useful for detection and identification of Brucella spp. and blood culture is known as the gold standard for Brucella spp. Diagnosis of brucellosis through polymerase chain reaction (PCR) could be more sensitive and specific than other classical methods such as blood culture and conventional serological tests. Until now different Brucella specific sequences like BCSP 31, IS711 and 16SrRNAwere amplified for detection of Brucella Spp. Results Amplification of extracted DNA from serum of 49 suspected patients were tested with two sets of specific primers. The BCSP31 sequence amplicon was $223 \mathrm{bp}$ and all the 49 (100\%) serum specimens isolated from suspected patients were positive by B4 and B5 primers, even the 4 cases out of $492 \mathrm{ME}$ negative samples were positive. Detection of Brucella in serum samples by designed IS711 primers revealed the amplicon of IS711 with $448 \mathrm{bp}$ length. Among the 49 serum samples isolated from patients, 46 (93.87\%) cases were positive. The B4-B5 primers and IS711 designed primer recognized 100\% (49/49) and 94\% (46/49) of the cases, respectively. Conclusion This study shows that the specificity of the 2 primer sets is $100 \%$ and the sensitivity of B4-B5 primers is $100 \%$, while the sensitivity of the designed primers of IS711 is $94 \%$. The B4-B5 primers can detect the least number of both B. melitensis and B. abortus, $0.05 \mathrm{CFU} /$ reaction. However, the designed IS711 set is able to detect $2 \mathrm{CFU} /$ reaction, about $2.5 \times 102$ times more sensitive than results of other experiments for detection of IS711 target sequence in the specimens.

\section{Background}

Brucellosis is a zoonotic infectious disease caused by different species of Brucella and can be transmitted from infected animals to humans by animal exudates or the consumption of unpasteurized dairy products $[1,2]$.

According to WHO (1997) reports, about 500,000 patients with brucellosis are reported annually while it is estimated that the number of patients is $10-25$ times higher than the reported cases. The majority of reported cases belong to the Middle East countries, including Iran, Iraq and the Persian Gulf Region countries [3]. In Iran, the frequency of reported brucellosis is 34 per 100,000 every year [4]. Moreover, the Mediterranean region and Latin America are both recognized as areas with high risk of brucellosis [5].

Brucella is a non-motile, gram-negative and intracellular coccobacillus including 4 human pathogenic species of $B$. canis, $B$. suis, $B$. abortus, $B$. melitensis $[2,6]$. Furthermore, there is high infection risk in some professions such as veterinarians, cowhands, laboratory staffs and slaughterhouse workers [7]. These bacteria causing severe infection in humans with non- specific clinical symptoms which are similar to other febrile diseases like malaria, tuberculosis, and typhoid fever. A confirmed diagnosis is required to isolate the bacterial agent from clinical specimens like blood, bone marrow, CSF or tissues $[8,9]$. Microbiological, serological and molecular approaches are useful for detection and identification of 
Brucella spp. and blood culture is known as the "gold standard" for Brucella spp. Nevertheless, the sensitivity of blood culture has been reported about $15 \%$ to $70 \%[10,11]$. As Brucella spp. are categorized in class 3 pathogens [12], detection and diagnosis of Brucella spp. in clinical samples via blood culture is contagious and time-consuming [5].

Although the serological tests used for Brucella spp. include a diversity of assays such as Rose Bengal, 2Mercaptoethanol, Coombs and Serum agglutination test [10], the specificity of these tests are low and are not suitable for endemic areas, and particularly for patients with chronic brucellosis [13]. Besides, the specificity of serological assays could be affected by cross-reactivity with other gram-negative bacteria, in the early stage of the disease $[14,15]$. However, the molecular techniques such as DNA-based tests has proved to be fast ( $>4 \mathrm{~h}$ ) [16], and DNA detection allows molecular typing of Brucella without handling the infective Brucella organism [17]. The amplification of BCSP 31 and IS711genes causes the identification

of the various Brucella species [18]. Sequencing the whole genome of B. abortus, B. melitensis, B.suis has revealed high degree of genetic homology (up to $99.9 \%$ ) in human pathogens and other species of Brucella [19], thus PCR as a nucleic acid amplification technique with high sensitivity and specificity can conquer the limitation of conventional methodology [20].

Therefore, in the present study, the PCR technique is used to detect the bacterial cells of Brucella spp. in serum samples of suspected patients with brucellosis clinical symptoms, by two primer sets. Each primer set is evaluated by comparing with the other one. These primers include B4-B5 primers and the designed primer of IS711 sequences.

\section{Methods}

\section{Area and time of study}

The patient samples were gathered from different provinces in Iran, during a period of 10 months (from October 2017 to July 2018). Two patients from Babol with geographical specification of latitude: $38^{\circ} 35$ ' $\mathrm{N}$ and longitude: $44^{\circ} 58^{\prime} \mathrm{E}$ at $211 \mathrm{~km}$ northeast of Tehran , 2 from Shiraz with latitude: $29^{\circ} 59^{\prime} \mathrm{N}$ and longitude: $52^{\circ} 58^{\prime} \mathrm{E}$ at $922 \mathrm{~km}$ south of Tehran , 6 patients from Mashhad with latitude: $36^{\circ} 20^{\prime} \mathrm{N}$ and longitude: $59^{\circ} 35^{\prime} \mathrm{E}$ at $898 \mathrm{~km}$ east of Tehran, 4 from Borujerd with latitude: $33^{\circ} 55^{\prime} \mathrm{N}$ and longitude: $48^{\circ}$ $50^{\prime} \mathrm{E}$ at $386 \mathrm{~km}$ southeast of Tehran, 4 from Urmia with latitude: $37^{\circ} 54^{\prime} \mathrm{N}$ and longitude: $45^{\circ} 07^{\prime} \mathrm{E}$ at $761 \mathrm{~km}$ northwest of Tehran, 3 from Makoo with latitude: $39^{\circ} 15^{\prime} \mathrm{N}$ and longitude: $44^{\circ} 31^{\prime} \mathrm{E}$ at $873 \mathrm{~km}$ northwest of Tehran,24 from Khoy with latitude: $44^{\circ} 58^{\prime} \mathrm{N}$ and longitude: $38^{\circ} 33^{\prime} \mathrm{E}$ at $782 \mathrm{~km}$ northwest of Tehran, and 4 from Tabriz with latitude: $38^{\circ} 09^{\prime} \mathrm{N}$ and longitude: $46^{\circ} 27^{\prime} \mathrm{E}$ at $618 \mathrm{~km}$ northwest of Tehran.

\section{Case definition and data collection}

Blood specimens were collected from 49 suspected cases of patients with brucellosis symptoms who were referred to diagnostic laboratories in different cities from northern ( 2 cases, $4.08 \%$ ), southern (2 cases, $4.08 \%$ ), western (39 cases, 79.59\%) and eastern $(6,12.24 \%)$ provinces in Iran, during a period of 10 months. Serum samples were processed on the same day as blood collection. Before blood collection, the 
written informed consent was obtained and the questionnaire which included age, genus, job, residence area, primary clinical symptoms was filled for each patient.

\section{Serological test:}

Prior to amplification, the isolated specimens (sera) were tested by the serological assay of $2 \mathrm{ME}$ (2Mercaptoethanol) test. Then, in accordance with standard methods, a positive $2 \mathrm{ME}$ titer was defined as either equal or greater than 1:80 and Coombs Wright titer was considered as either equal or greater than 1:80 [21]. In this study, we gathered samples from suspected patients which their titer of the 2ME test was equal or higher than $1 / 20$ and serial dilutions of serum samples were prepared as follows: 1/2, 1/10, $1 / 20,1 / 40,1 / 80,1 / 160,1 / 320,1 / 640,1 / 1280$. The serological tests were checked by positive and negative controls [21].

\section{Bacterial DNA extraction}

The viable bacterial samples of $B$. melitensis and $B$. abortus were provided from the microbial culture collection of Department of Microbiology, Faculty of Veterinary Medicine, University of Tehran. The DNA templates belonging to the aforementioned bacteria were extracted by the commercial kit (GTP. Tehran, Iran). The purified genomic DNA was stored at $-20^{\circ} \mathrm{C}$ until the day of amplification, followed by a serial dilution of purified DNA and the DNA of Escherichia coli was extracted and used as the negative control.

\section{Extraction of DNA from serum samples}

The isolated patient serum samples were kept in tubes containing sodium citrate. The DNA was extracted from the serum specimens of $200 \mu \mathrm{L}$ volume, according to the guideline of the kit.

\section{Bioinformatics analyses, primer design and DNA amplification}

Two primer sets with different target genes were used after bioinformatics analysis:

First, B4 (5'-TGG CTC GGT TGC CAA TAT CAA-3') and B5 (5'-CGC GCT TGC CTT TCA GGT CTG-3'), with a target gene encoding a $31-\mathrm{kDa} B$. abortus antigen which is a conserved sequence in all species of Brucella [22]. The reaction was consisted of $12.5 \mu \mathrm{L} 2 \mathrm{X}$ PCR master mix (Amplicon, Denmark), $5 \mu \mathrm{L}$ DNA template, $0.5 \mu \mathrm{L}$ of each primer and nuclease-free water up to $25 \mu \mathrm{L}$. The amplification was done with Techne, touch gene gradient PCR machine, model: Techne TC-512 (WWW.Techne.com). The thermo-cycler was programmed as follows: Initial denaturation at $95^{\circ} \mathrm{C}$ for $5 \mathrm{~min}, 35$ cycles of template denaturation at $94^{\circ} \mathrm{C}$ for $1 \mathrm{~min}, 30 \mathrm{~S}$ for primer annealing at $60^{\circ} \mathrm{C}$ and $60 \mathrm{~S}$ for primer extension at $72^{\circ} \mathrm{C}$ with final extension cycle at $72^{\circ} \mathrm{C}$ for $7 \mathrm{~min}$.

Second, IS711 specific primer which was designed based on the sequence of $B$. melitensis deposited in the GenBank. The primer was designed applying Codoncode Aligner software (V.7.1.2)). The designed primers, F (5'-CGC TCG CTG CCA TAC TTG CA-3') and R (5'-CTG AAC AAG CCG GGC CTG AT-3') amplified a 448 bp fragment which was a repetitive genetic element of IS711 and was unique to Brucella species. 
At least, one copy of this repetitive genetic element may appear as a common locus in all species of Brucella [6]. The IS711 PCR assay was carried out in total volume of $25 \mu \mathrm{L}$ containing the same mixture which was used for PCR. The gene amplification using the IS711 primer was programmed as follows: initial denaturation at $95^{\circ} \mathrm{C}$ for $5 \mathrm{~min} .35$ cycles of template denaturation at $94^{\circ} \mathrm{C}$ for $1 \mathrm{~min}, 60 \mathrm{~S}$ for primer annealing at $63^{\circ} \mathrm{C}$ and $60 \mathrm{~S}$ for primer extension at $72^{\circ} \mathrm{C}$ with final extension cycle at $72^{\circ} \mathrm{C}$ for 7 $\min$.

In each PCR assay, a positive control, extracted DNA from B. melitensis Rev. 1 and B.abortus S19 and negative control, extracted DNA from E. coli (ATCC 35218) were applied to control the running process and the absence of cross-contamination. All the standard items were checked for prevention of any probable contamination [23]. The tests were carried out twice. After the amplification process, the samples were run on $1 \%$ agarose gel (Sigma). The gel was stained by $1 \mu \mathrm{g} / \mathrm{ml}$ ethidium bromide and after destaining, the DNA bands were visualized within Gel documentation UV chamber.

\section{Sensitivity assay}

In the current study, for colony forming unit (CFU) estimation, a 48h incubated suspension of $B$. melitensis and $B$. abortus within sterile PBS was used for preparing serial dilutions from $10^{-1}$ to $10^{-10}$. From each dilution, $0.1 \mathrm{ml}$ was streaked onto the Brucella agar and was incubated at $37^{\circ} \mathrm{C}$ for $72 \mathrm{~h}$. Then, the colonies of $B$. melitensis and $B$. abortus were counted [24] and the bacterial concentration was calculated to be about $5 \times 10^{8} \mathrm{CFU} / \mathrm{ml}$ for both $B$. melitensis and $B$. abortus. Then a serial dilution of extracted purified DNA of $B$. melitensis and B. abortus was prepared from $10^{-1}$ to $10^{-10}$. Afterwards, five microliters of each dilution was used as template in the PCR process. No amplification was detected with E. coli DNA template. The tests were carried out twice.

\section{Results}

\section{Epidemiologic data}

In this research, the geographical distribution of patients in different cities was as follows; Khoy: $48.97 \%$, Mashhad: 12.24\%, Tabriz and Urmia: 8.1\%, Makoo, and Borujerd: 6.1\%, Shiraz and Babol: 4.08 \% (Figure 1).

Based on the collected data, $83.67 \%$ and $16.37 \%$ of the patients were men and women, respectively (Figure 2). The age of the patient ranged within 18 to 70 years old with the average of 33.02 years old. The Patient age groups consist of 1 patient under 20, 14 patients between 20-30, 27 patients between 3040, 4 patients between 40-50, 2 patients between 50-60, and 1 patient over 60 years old (Figure 3).

The job of $32(65.30 \%)$ patients was stockbreeding, 5 (10.20\%) patients were dairy industries staff, 1 (2.04\%) patient was the hospital nurse and 11 (22.44\%) patients had miscellaneous jobs (Figure 4). All the patients had clinical symptoms representing brucellosis. 
In this study, $2 \mathrm{ME}$ test result revealed serum titers ranging from 1:20 to 1: 1280.The result of the $2 \mathrm{ME}$ test in 49 serum samples was $3(6.12 \%)$ patient with 1: 20 titer, 1 (2.04\%) patient with 1: 40, $29(59.18 \% \%)$ patient with 1: $80,9(18.36 \%)$ patient with 1: 160,1 (2.04\%) patient with 1: 320 and 4 (12.24\%) patients with 1: 640 titer, 2 patients with 1/1280 (Figure 5).

Amplification with BCSP31-PCR

The result of Detecting the Brucella genus with B4 and B5 primers is shown in figure 6. As expected, the BCSP31 gene amplicon size was $223 \mathrm{bp}$, and all the 49 (100\%) serum specimens isolated from patients were positive by B4 and B5 primers, even the 4 cases out of $492 \mathrm{ME}$ negative samples were positive in this PCR running.

Amplification with IS711-PCR

Detection of Brucella in serum samples was performed by designed IS711 primers which were specific to Brucella genus. The positive result is shown in figure 7. The amplicon of IS711 is $448 \mathrm{bp}$. Among the 49 serum samples isolated from patients, $46(93.87 \%)$ cases were positive.

Evaluation of the sensitivities of studied primer pairs

The sensitivities of the applied primers (B4-B5 and IS711) were evaluated by using serial dilutions of extracted purified DNA molecules of $B$. melitensis and $B$. abortus. The comparative values of related primers are indicated in figure 8 and 9 . The B4-B5 primers were able to detect bacterial cells with the amount of $0.05 \mathrm{CFU} /$ reaction for both $B$. melitensis and $B$. abortus, while the IS711 novel primer was able to detect bacterial cells with the amount of $2 \mathrm{CFU} /$ reaction for both them. Since it has been estimated that 20 Brucella cells are equal with $60 \mathrm{fg}$ of bacterial DNAs [22], It is estimated that B4-B5 primers are able to detect $1.5 \mathrm{pg}$ of DNA while the novel primers of IS711 are able to detect the amount of $0.6 \mathrm{ng}$ of DNA.

\section{Discussion}

Generally, the conventional classic diagnostic methods for detection of brucellosis have low sensitivity and specificity, with a high risk of incorrect diagnosis which may lead to mistreatment $[25,26]$. In contrast, the advanced molecular diagnostic tools are a reliable methodology to gain accurate and sharp results within a short time. Among different types of molecular tools, PCR is a sharp, accurate and reliable diagnostic method with high sensitivity. The PCR, as well as other molecular technologies, needs to be optimized; thus, optimization should be done to have an accurate and sharp outcome [25,26]. Each method has its own limitations, the reason why there should be a harmony between the type of procedures, samples, methodologies and the outcome. These items have direct effects on the diagnostic outcomes [26]. Other techniques like culture media and serological assays are time-consuming [8]. Furthermore, in accordance with previous reports molecular techniques such as PCR are known as gold 
molecular options for detection and identification of fastidious bacteria like Brucella [18]. Among different species of Brucella, B. melitensis is the main causative agent for human brucellosis in Middle East countries involving Iran and Iraq, Syria and India [27, 28].

In this project, men (83.67\%) were infected with Brucella is more than women (16.37\%), group age of 3040 years $(55.1 \%)$ had the highest infection and the highest job exposure was in stockbreeders $(65.30 \%)$.

In the current research, the PCR as a member of nucleic acid amplification techniques (NAAT) was used for detection of Brucella spp. isolated from serum specimens taken from patients with brucellosis in different geographic areas of Iran. For this purpose, 49 serum samples were isolated from patients with brucellosis. In this study, two types of primers including B4-B5 and IS711 were compared with each other to have an evaluation of their sensitivity and specificity. It is recommended that the $2 \mathrm{ME}$ titers of less than 1: 80 should not be ignored without moreover follow-ups. However, the $2 \mathrm{ME}$ titer of $1: 80$ is not denotative of active infection, especially in endemic regions [29, 30, 31]. The 2ME test could be used to forecast the course of the disease [32] and also proved useful to monitor antibiotic therapy [33]. So, the sensitivity and specificity of two targets, BCSP 31 and designed IS711 genes were compared by PCR in comparison with $2 \mathrm{ME}$. In this experiment, the sensitivity and specificity of different PCR protocols using BCSP31 target sequence for detection of Brucella DNA in human blood or serum samples varies between $50 \%$ and $100 \%$, respectively $[34,35]$. The specificity of the B4-B5 PCR assay, as well as the other primer pair assays, was excellent according to previous results [22, 34, 36, 37, 38]. Our results indicated that the PCR assay with designed primers of IS711 detected the high number of samples containing Brucella spp. in $2 \mathrm{ME}$ - positive and negative serum samples. These primers could detect at least $0.2 \times 10^{1} \mathrm{CFU} / \mathrm{ml}$ bacteria in the samples, approximately $2.5 \times 10^{2}$ times more sensitive than the other IS711 primers were used in the detection of this gene by Ciftciin, which could detect $5 \times 10^{2} \mathrm{CFU} / \mathrm{ml}$ bacteria [26]. These achievements confirm the PCR results that were reported by Khosravi [39] and Elfaki [40]. In these studies, a large number of samples containing $B$. melitensis DNA were detected by using the IS711primers. However, our findings are significantly different from the reported results by Garshasbi. In the performed study by Garshasbi, the sensitivity is low and a large number of $B$. abortus was detectable by using the IS711 primers [18].

In this PCR assay, the amplified DNA was purified from the serum sample instead of whole blood. The whole blood samples contain more inhibitors than serum samples. Besides, the DNA extraction from serum sample is more efficient than the whole blood. Heparin is known as a PCR inhibitor that inhibits Taq DNA polymerase and EDTA acts by chelating $\mathrm{Mg}^{2+}$ ions. Sodium citrate is a good alternative to be used instead of heparin or EDTA [38].

In the current study, the use of diluted Brucella DNA (1 to 10 in water) did not improve the overall sensitivity of the B4-B5 or IS711 primer pairs and was not accepted as a routine step. Moreover, the detection of Brucella is limited to $0.05 \mathrm{CFU} /$ reaction by B4-B5 primers with $100 \%$ sensitivity, while the detection is limited to $2 \mathrm{CFU} /$ reaction by designed IS711 primer with $93.87 \%$ sensitivity. The negative results for detection of Brucella in the 3 samples suggested that they had inadequate number of bacteria 
detectable by IS711 primer. It is worthwhile to mention that different amounts of template DNA were used ranging from 1 to $5 \mu \mathrm{L}$ to eliminate the possible reaction inhibition of the template DNA inhibitors.

\section{Conclusion}

Application of the IS711 and the BCSP31-based PCR assays in this survey is a promising method for detection and identification of Brucella spp, as routine clinical diagnostic procedure in microbiology laboratories, since the PCR assays reduce the risk of working with infective microorganisms in the laboratories [18]. Our findings in this study have shown $100 \%$ sensitivity and $100 \%$ specificity for B4-B5 specific PCR. The sensitivity and specificity of IS711 sequence specific PCR in comparison with the 2ME test were $94 \%$ and $100 \%$, respectively. The aim of this study was to develop a novel molecular method for detection and identification of Brucella spp. However, the gold standard diagnostic method for brucellosis both in animals and humans is still based on the isolation of Brucella spp. within the specimens [38].

\section{Abbreviations}

ATCC: American type culture collection; BCSP: Brucella cell surface protein; CFU: Colony forming unit; CSF: Cerebrospinal fluid; DNA: Deoxyribonucleic acid; EDTA: Ethylenediaminetetraacetic acid; fg: Femtogram; IS711: Insertion sequence711; NAAT; Nucleic acid amplification technique; ng: Nanogram; PBS: Phosphate buffer saline; PCR: Polymerase chain reaction; WHO: World health organization; 2ME: 2 Mercaptoethanol.

\section{Declarations}

\section{Ethics approval and consent to participate}

The study was approved by the Faculty of Medicine, Tehran Islamic Azad University of Medical Sciences, Research Ethics Committee, with approval ID: IR. IUA. TMU. REC: 1397. 245.

The present study involved the clinical samples of suspected patients with brucellosis symptoms who were referred to diagnostic microbiology laboratories in the studied geographical areas.

The written informed consent was obtained prior to taking blood and the questionnaire which included age, genus, job, residence area, primary clinical symptoms was filled for each patient.

\section{Consent for publication}

Not applicable.

\section{Availability of data and material}

The accession numbers of Brucella used for the primers design in November 2017 are as follows: AM040246 - AF036614 - AF047478 - DQ845343 - JF939171 - KF730265 - HM598413 - JN561159 
- JN561158 - GQ443747 - GQ479519 - HM598412.

\section{Competing interests}

The authors declare that they have no competing interests.

\section{Funding}

This work was not supported by any kind of financial support.

\section{Authors' contributions}

PH and MRR conceived anddesigned the study; PH and MRR performed the experiments; MS and AAS advised the research; $\mathrm{PH}, \mathrm{MRR}$ and AAS analyzed the data; $\mathrm{PH}$ wrote the manuscript; MRR revised the manuscript. All authors read and approved the final manuscript.

\section{Acknowledgements}

The authors wish to thank Dr. Alireza Nadji, head virology department of Masih-Daneshvari hospital also, laboratory staffs and personnel of Shiraz, Urmia, Tabriz, Khoy, Borujerd, Mashhad, and Makoo cities for providing the specimens.

\section{Authors' information}

1. Pedram Heidari, Department of Microbiology, Faculty of Basic Sciences, Islamic Azad University, North Tehran Branch, Tehran, Iran, Postal Code: 1667934783, e-mail: heidaripedram@gmail.com, Tel: +98912 1791427.

2. Mitra Salehi, Department of Microbiology, Faculty of Basic Sciences, Islamic Azad University, North Tehran Branch, Tehran, Iran, Postal Code: 1667934783, e-mail: m_salehi@lau-Tnb.ac.ir, Tel: +98912 3211794.

3. Abbas Akhavan Sepahi, Department of Microbiology, Faculty of Basic Sciences, Islamic Azad University, North Tehran Branch, Tehran, Iran, Postal Code: 1667934783, e-mail: a_akhavan@lauTnb.ac.ir, Tel: +989121547166.

4. Mohamad Reza Razaviab (with two valid affiliations)

${ }^{a}$ Molecular Parasitology Laboratory, Department of Parasitology, Pasteur Institute of Iran, Tehran, Iran.

${ }^{\mathrm{b}}$ Microbiology Research Center, Pasteur Institute of Iran, Tehran, Iran.

Corresponding Author: Mohamad Reza Razavi

E-mail: mrrazavi@pasteur.ac.ir 
Mailing address: Molecular Parasitology Laboratory, Pasteur Institute of Iran, 69 Pasteur Avenue, Postal code: 1316943551 Tehran, Iran Tel: +982164112257, Fax: +982166968855,

Cell: +989126157325.

\section{References}

1. Corbel MJ: Brucellosis: an overview. Emerg Infect Dis 1997; 3:213-221. 2. Kamal IH, AL Gashgari B, Moselhy SS, Kumosani TA, Abulnaja KO: Two-stage PCR assay for detection of human brucellosis in endemic areas. BMC Infect Dis 2013; 13:145-149. 3. Pappas G, Papadimitriou P, Akritidis N, Christou L, Tsianos EV: The new global map of human brucellosis. Lancet Infect Dis 2006; 6:91-99. 4. Najafi N, Ghassemian R, Davoody AR, Tayebi A: An unusual complication of a common endemic disease: clinical and laboratory aspects of patients with Brucella epididymoorchitis in the north of Iran. BMC Res Notes 2011; 4:286-289. 5. Yagupsky P: Detection of Brucella in Blood Cultures. J Clin Microbiol 1999; 37(11):3437-3442. 6. Bricker BJ, Halling SM: Differentiation of Brucella abortus bv. 1, 2, and 4, Brucella melitensis, Brucella ovis, and Brucella suis bv. 1 by PCR. J Clin Microbiol 1994; 32(11):2660-2666. 7. Sofian M, Aghakhani A, Velayati AA, Banifazl M, Eslamifar A, Ramezani A: Risk factors for human brucellosis in Iran: a case-control study. Int J Infect Dis 2008; 12:157-161. 8. Al Dahouk S, Nockler K: Implications of laboratory diagnosis on brucellosis therapy. Expert Rev Anti Infect Ther 2011; 9:833-845. 9. Al Dahouk S, Tomaso H, Nöckler K, Neubauer H, Frangoulidis D: Laboratory-based diagnosis of brucellosis-a review of the literature. Part 1: Technique for detection and identification of Brucella spp. Clinical Laboratory 2003; 49:487-505. 10. Alves CJ, Figueiredo SM, Azevedo SS, Clementino IJ, Keid LB, Vasconcellos SA, Batista CSA, Rocha VCM, Higino SS: Detection of Brucella ovis in ovine from Paraíba State, in the Northeast region of Brazil. Brazilian Journal of Microbiology 2010; 41:365-367. 11. SanjuanJimenez R, Colmenero JD, Morata P: Lessons learned with molecular methods targeting the BCSP-31 membrane protein for diagnosis of human brucellosis. Clin Chim Acta 2017; 469:1-9. 12. Pike RM, Sulkin SE, Schulze ML: Continuing importance of laboratory-acquired infectious. Am J Public Health 1965; 55:190-199. 13. Christopher S, Umapathy BL, Ravikumar KL: Brucellosis: review on the recent trends in pathogenicity and laboratory diagnosis. J Lab Physicians 2010; 2:55-60. 14. Young EJ: Serologic diagnosis of human brucellosis: analysis of 214 cases by agglutination tests and review of the literature. Rev Infect Dis 1991; 13:359-372. 15. Ariza J, Pellicer T, Pallares R, Foz A, Gudiol F: Specific antibody profile in human brucellosis. Clin Infect Dis 1992; 14:131-140. 16. Shakerian A, Permal D, Rahimi E, Shahjavan A, Khamesipour F: Molecular detection of Brucella melitensis in sheep and goat milk in Iran. Tropical Journal of Pharmaceutical Research 2016; 15 (5): 913-918. 17. Lindahl-Rajala E, Hoffman T, Fretin D, Godfroid J, Sattorov N, Boqvist S, Lundkvist A, Magnusso U: Detection and characterization of Brucella spp. in bovine milk in small-scale urban and peri-urban farming in Tajikistan. PLoS Negl Trop Dis 2017; 11(3):1-12. 18. Garshasbi M, Ramazani A, Sorouri R, Javani S, Moradi S: Molecular detection of Brucella species in patient suspicious of brucellosis from Zanjan, Iran. Brazilian J Microbiol 2014; 45: 533-538. 19. Kaden R, Ferrari S, Alm E, Wahab T: A novel real-time PCR assay for specific detection of Brucella melitensis. BMC Infectious Diseases 2017; 17:230-. 20. Romero C, Gamazo C, Pardo M, LópezGoñi I: Specific detection of Brucella DNA by PCR. J Clin Microbiol 1995; 33(3):615-617. 21. Colmenero 
JD, Munoz-Roca NL, Bermudez P, Plata A, Villalobos A, Reguera JM: Clinical findings, diagnostic approach, and outcome of Brucella melitensis epididymoorchitis. Diagn Microbiol Infect Dis 2007; 57 : 367-372. 22. Baily GG, Krahn JB, Drasar BS, Stoker NG: Detection of Brucella melitensis and Brucella abortus by DNA amplification. J Trop Med Hyg 1992; 95(4): 271-275. 23. Kwok S, Higushii R: Avoiding false positives by PCR. Nature 1989; 339:237-238. 24. Leyla G, Kadri GC, Umran O: Comparison of polymerase chain reaction and bacteriological culture for the diagnosis of sheep brucellosis using aborted fetus samples. Vet Microbiol 2003; 93:53-61. 25. Geresu MA, Kassa GM: A review on diagnostic methods of brucellosis. J Vet Sci Technol 2016; doi: 10.4172/2157-7579.1000323. 26. .Ciftci A, Ica tuba, Savasan S, Sareyyupoglu B, Akan M, Diker KS: Evaluation of PCR methods for detection of Brucella strains from culture and tissues. Trop Anim Health Prod 2017; 49: 755-763. 27. Bamaiyi PH, Hassan L, Khairani-Bejo S, Zainal-Abidin M: Update on Brucellosis in Malaysia and Southeast Asia. Malaysian J Vet Res 2014; 5(1):71-82. 28. Barua A, Kumar A, Thavaselvam D, Prakash A: Isolation and characterization of Brucella melitensis isolated from patients suspected for human brucellosis in India. Indian J Med Res 2016; 143:652-658. 29. Mantur BG, Biradar MS, Bidri RC, Mulimani MS, Veerappa Kariholu P, Patil SB, Mangalgi SS: Protean clinical manifestations and diagnostic challenges of human brucellosis in adults: 16 years' experience in an endemic area. J Med Microbiol 2006; 55: 897-903. 30. El Kholy AA, Gomaa HE, El Anany MG, Abd El Rasheed E: Diagnosis of human brucellosis in Egypt by polymerase chain reaction. East Mediterr Health J 2009; 15(5):1068-1074 31. Gemechu MY, Singh-Gill JP, Arora AK, Ghatak S, KumarSingh DK: Polymerase chain reaction (PCR) assay for rapid diagnosis and its role in prevention of human brucellosis in Punjab, India. Int J Prev Med 2011; 2(3):170-177. 32. Pabuccuoglu O, Ecemis T, EL S, Coskun A, Akcali S, Sanlidag T: Evaluation of Serological Tests for Diagnosis of Brucellosis. Jpn. J. Infect. Dis 2011; 64(4):272-276. 33. Buchanan TM, Faber LC: 2 Mercaptoethanol Brucella agglutination test: Usefulness for predicting recovery from Brucellosis. J Clin Microbiol 1980; 11(6):691-693. 34. Queipo-Ortuno MI, Morata P, Ocon P, Manchado P, Colmenero JD: Rapid diagnosis of human brucellosis by peripheral-blood PCR assay. J Clin Microbiol 1997; 35(11):2927-2930. 35. Al-Ajlan HH, Ibrahim AS, AlSalamah AA: Comparison of different PCR methods for detection of Brucella spp. in human blood samples. Pol J Microbiol 2011; 60(1):27-33. 36. Queipo-Ortuno MI Colmenero JD, Reguera JM, GarciaOrdonez MA, Pachon ME, Gonzalez M, Morata P: Rapid diagnosis of human brucellosis by SYBR Green Ibased real-time PCR assay and melting curve analysis in serum samples. Clin Microbiol Infect 2005; 11:713-718. 37. Navarro E, Fernandez JA, Escribano J, Solera J: PCR assay for diagnosis of human brucellosis. J Clin Microbiol 1999; 37(5):1654-1655. 38. Zerva L, Bourantas K, Mitka S, Kansouzidou A, Legakis NJ. Serum is the preferred clinical specimen for diagnosis of human brucellosis by PCR. J Clin Microbiol 2001; 39:1661-1664. 39. Khosravi AD, Abassi E, Alavi SM: Isolation of Brucella melitensis and Brucella abortus from brucellosis patients by conventional culture method and polymerase chain reaction technique. Pak J Med Sci 2006; 22(4):396-400. 40. Elfaki M, Uz-Zaman T, Al-Hokail A, Nakeeb S: Detection of Brucella DNA in sera from patients with brucellosis by polymerase chain reaction. Diagn Microbiol Infect Dis 2005; 53:1-7.

\section{Figures}




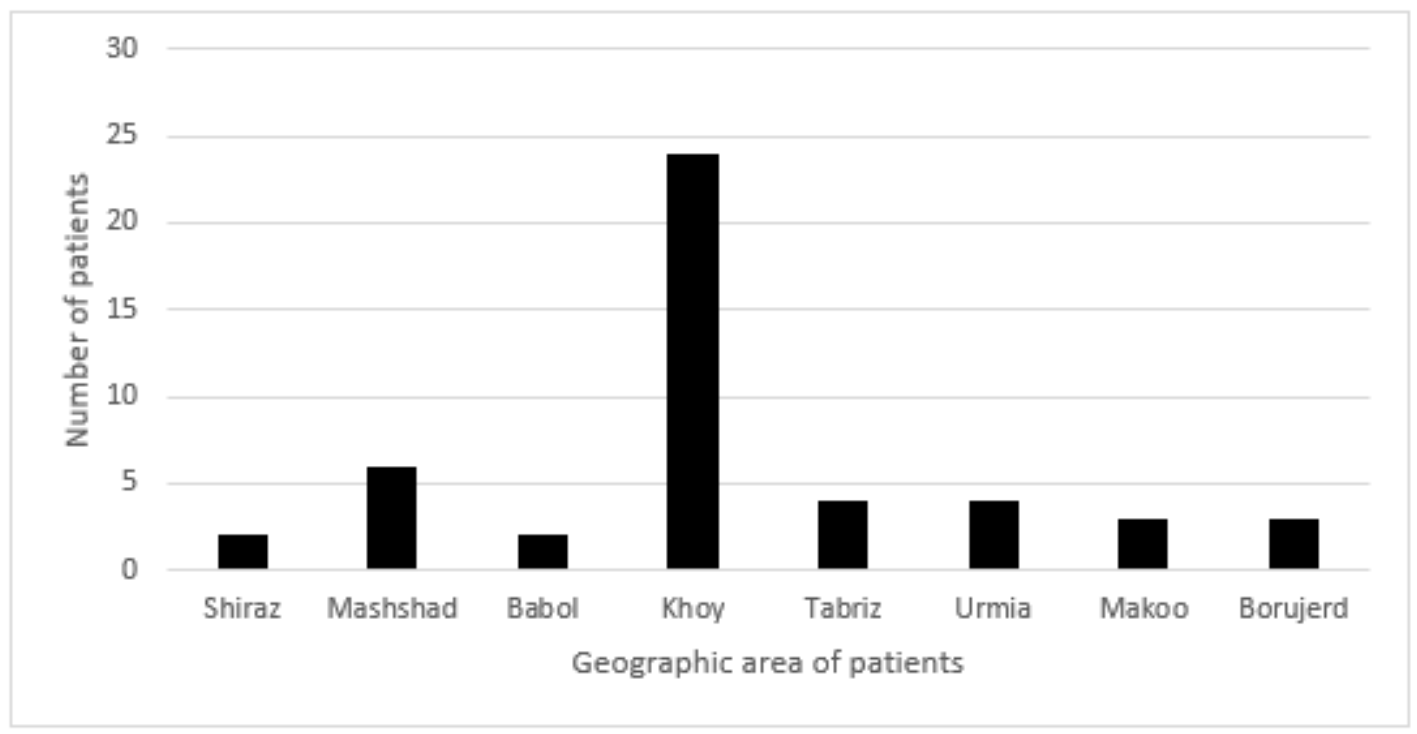

\section{Figure 1}

Geographical distribution of the studied patients

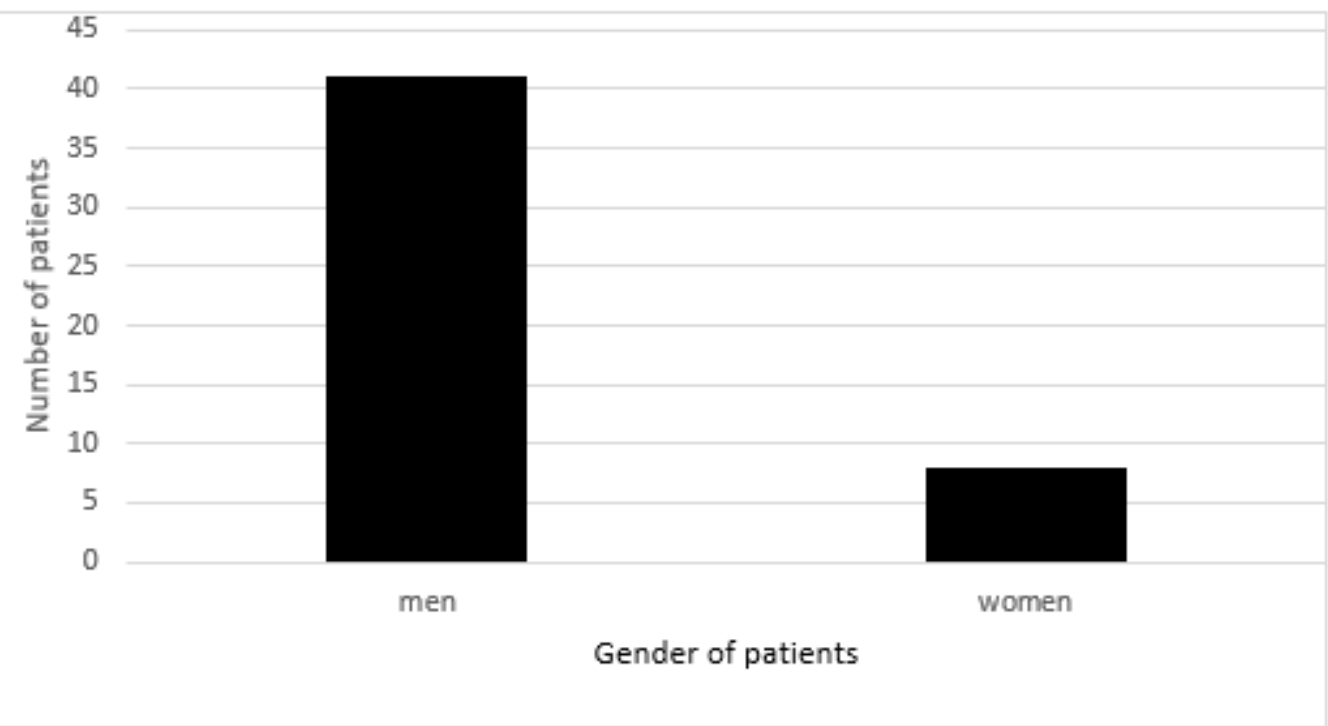

\section{Figure 2}

Gender distribution of the studied patients 


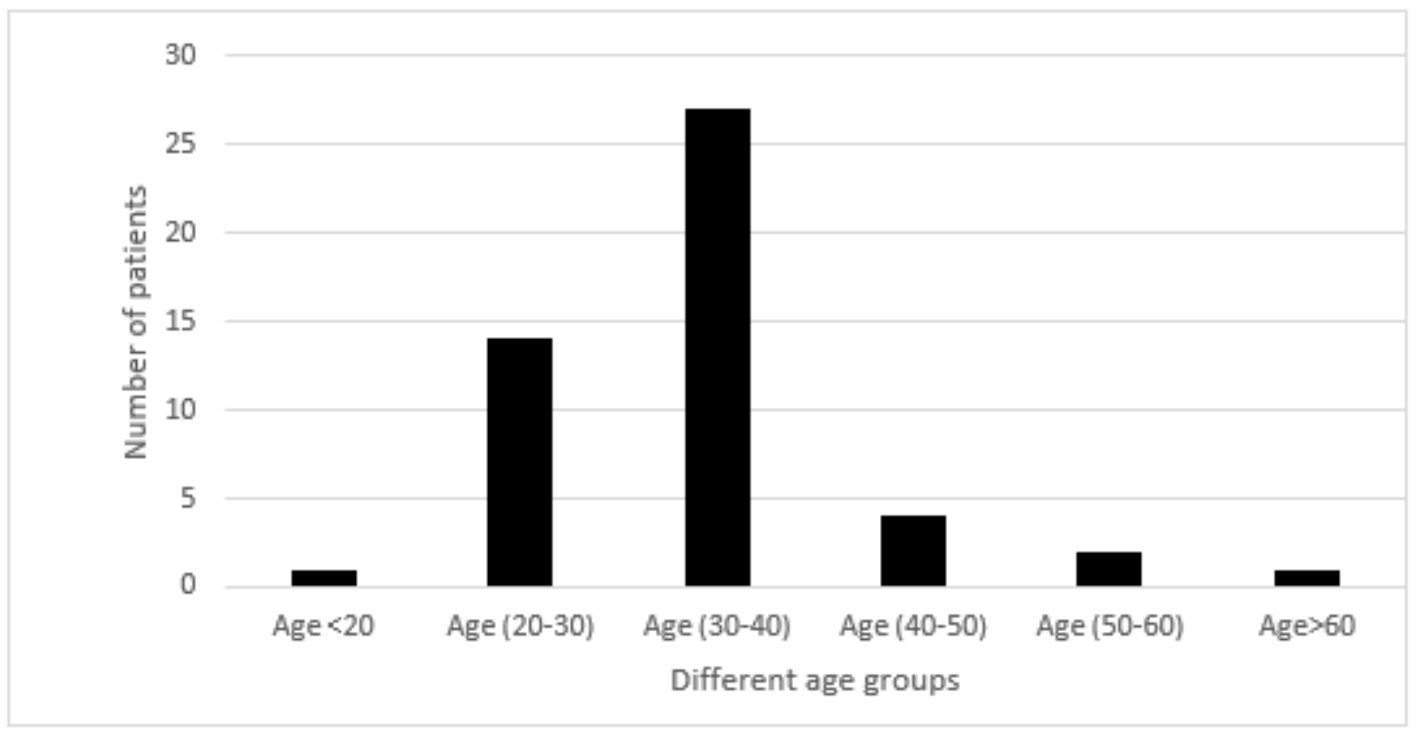

Figure 3

Age distribution of the studied patients

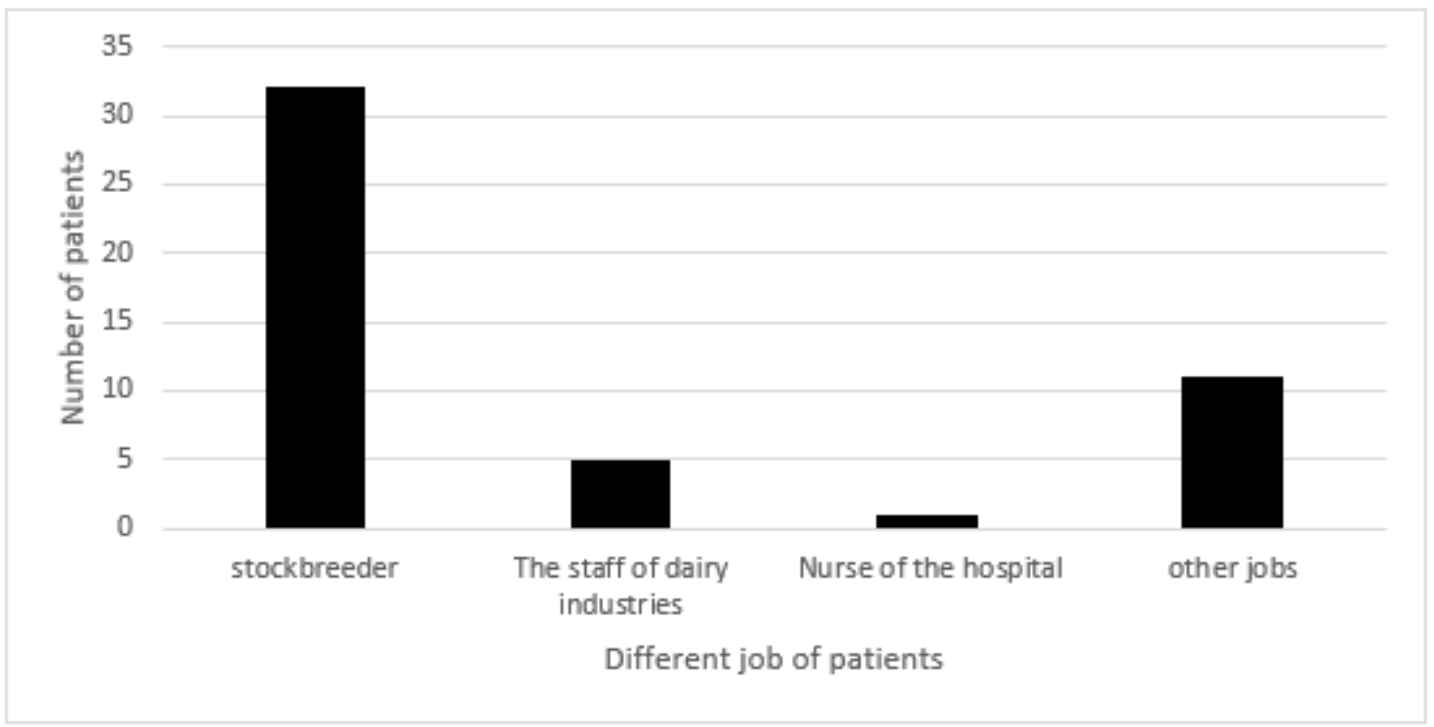

Figure 4

Occupations of the studied patients 


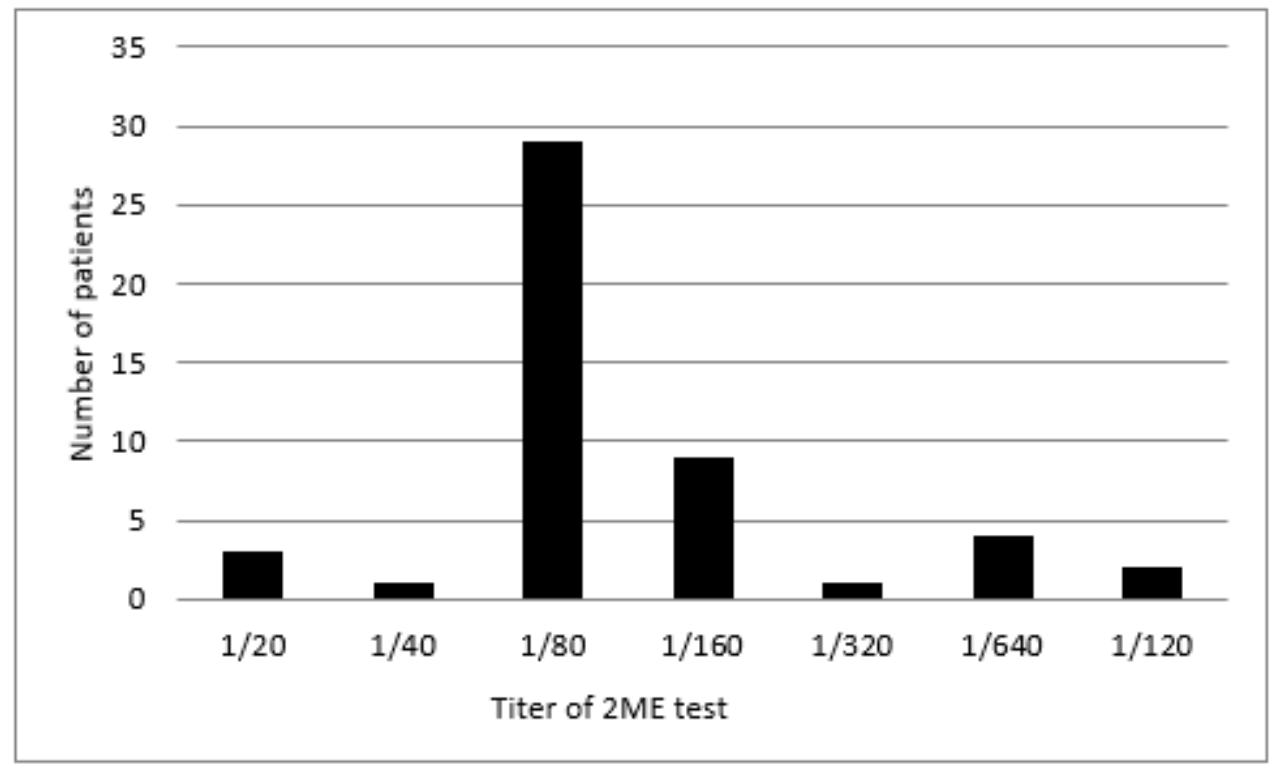

Figure 5

Results of $2 \mathrm{ME}$ test

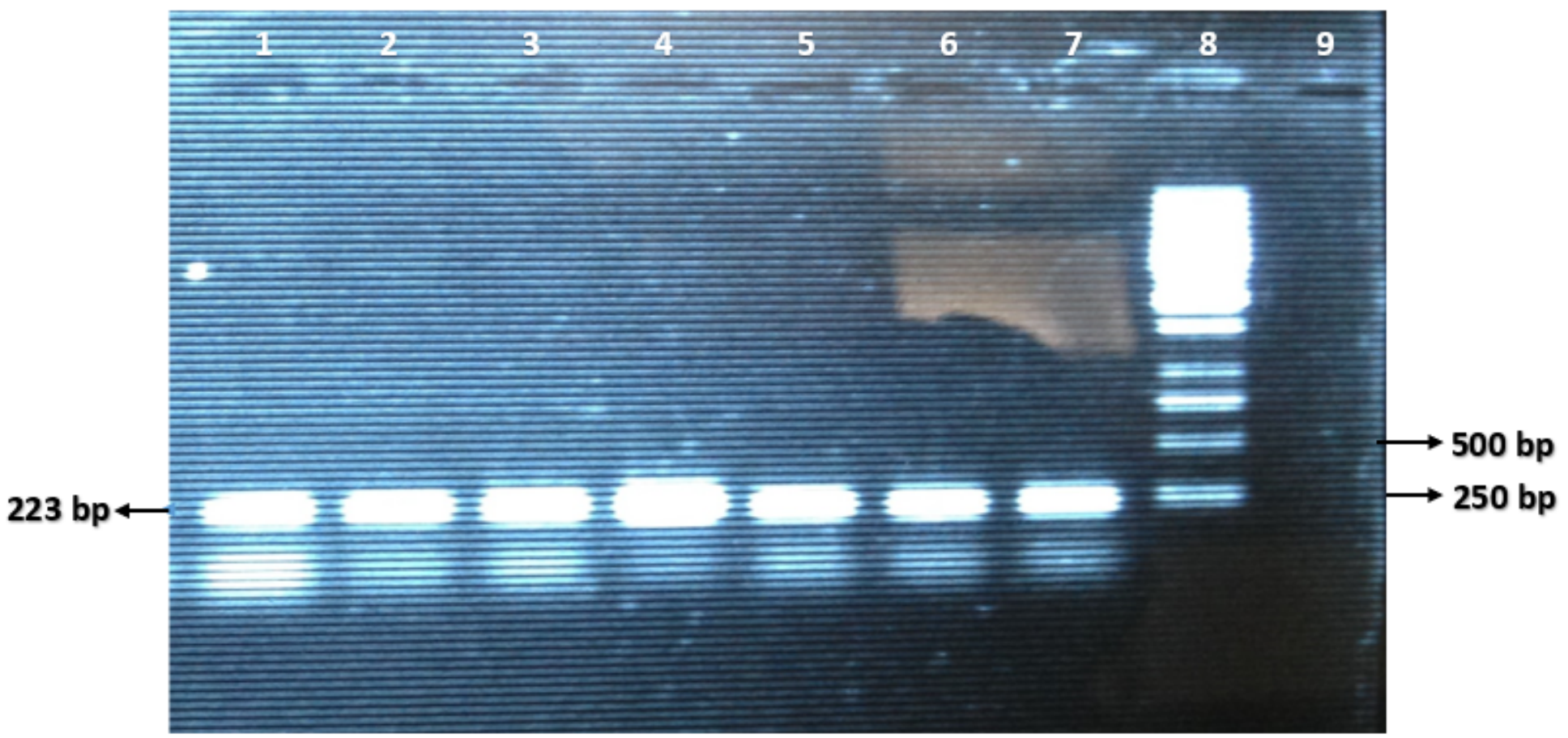

Figure 6

Detection of DNA amplified fragments with B4-B5 specific primers by $1.2 \%$ agarose gel electrophoresis and ethidium bromide staining. An amplicon size of 223 bp was obtained in the gel. Lanes: 1-6, serum samples; 7, positive control (B. melitensis); 8, 1 kb ladder (MBI-Fermentas) ; 9, E. coli as negative control. 


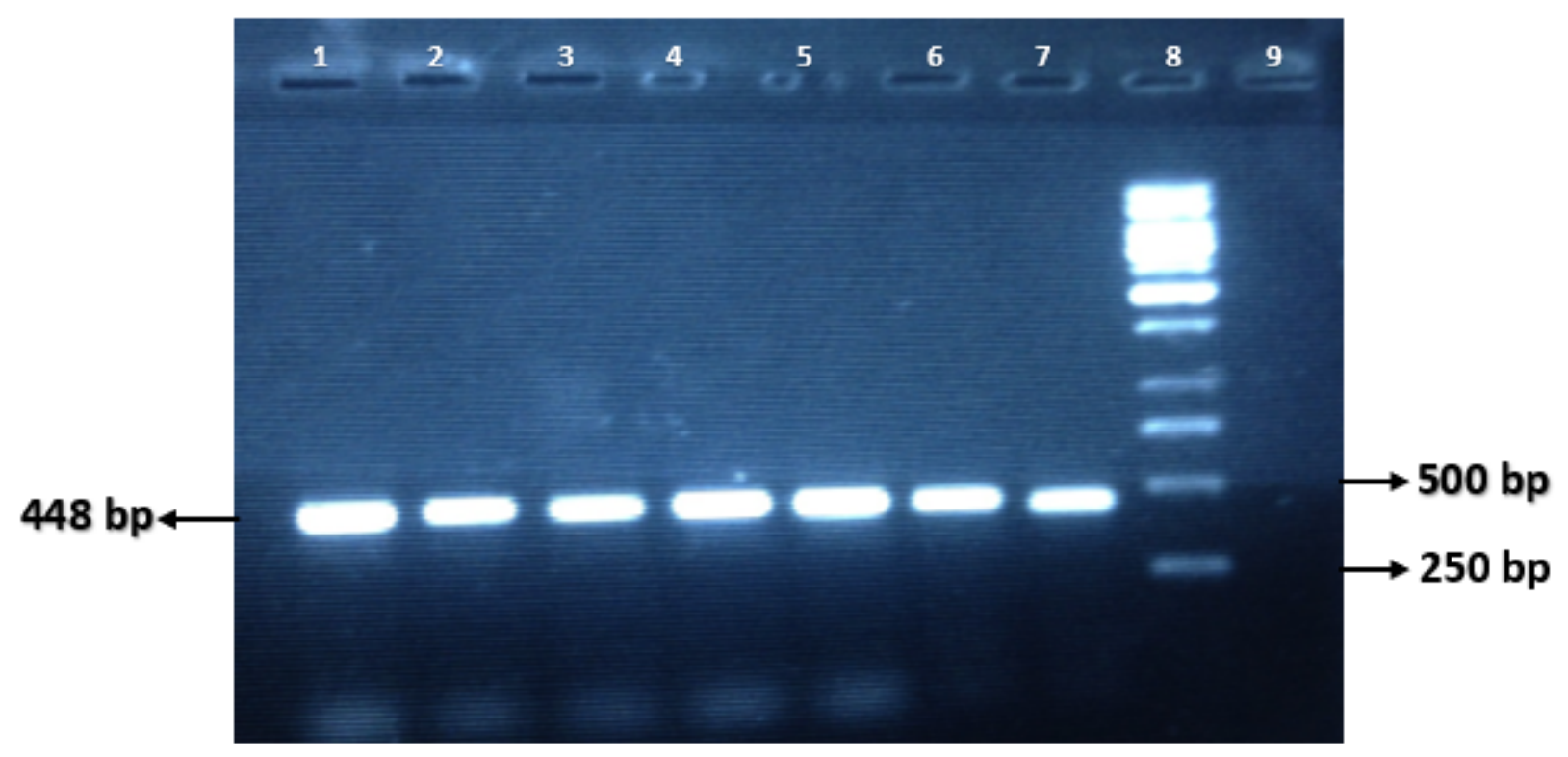

Figure 7

Detection of DNA amplified fragments with novel IS711 specific primers by $1.2 \%$ agarose gel electrophoresis and ethidium bromide staining. An amplicon size of 448 bp was obtained by PCR using B. melitensis - specific primers (IS711) and patients' serum DNA as the template. Lanes: 1-6, serum samples; 7, positive control (B. melitensis) ; 8, 1 kb ladder (MBI-Fermentas); 9, E. coli as negative control.

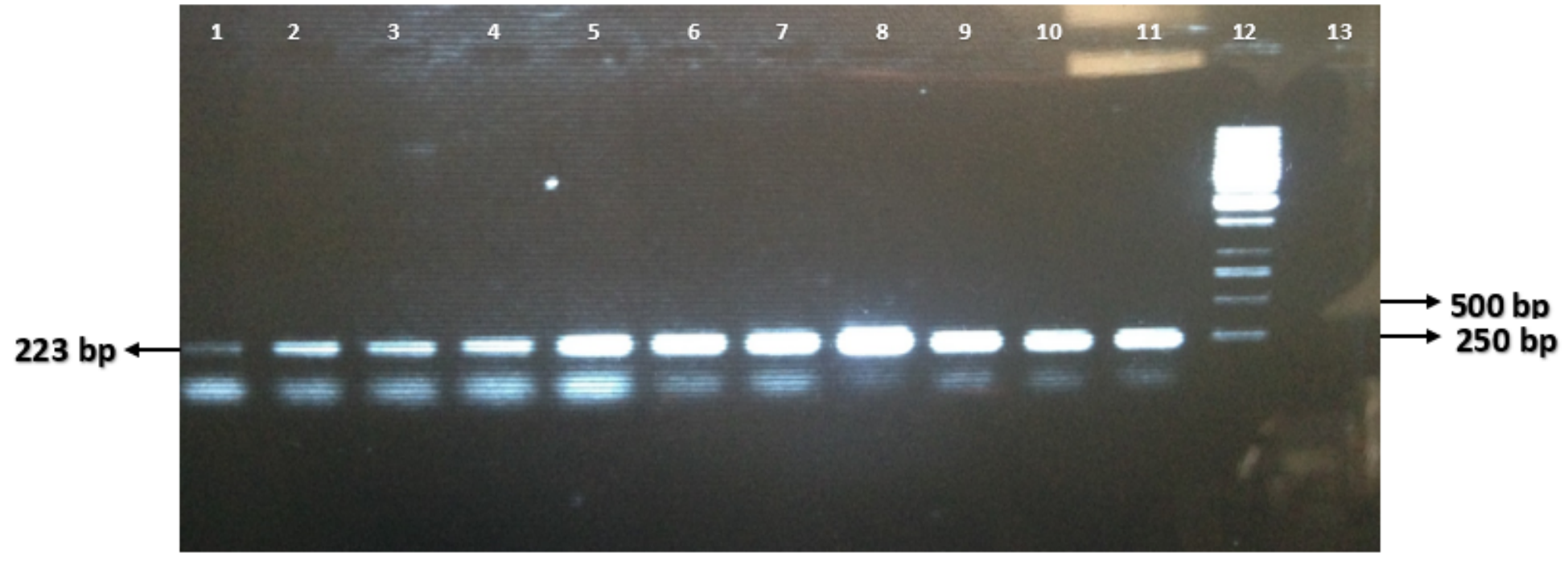

Figure 8

PCR products derived from10- fold serial dilutions of Brucella spp. DNA from 10-1-10-10 and B4-B5 primers. .Lanes: 1-10 diluted DNA from 10-10-10-1, respectively; 11, positive control (B. melitensis); 12, 1 kb ladder ( MBI-Fermentas) ;13, E. coli as negative control. 


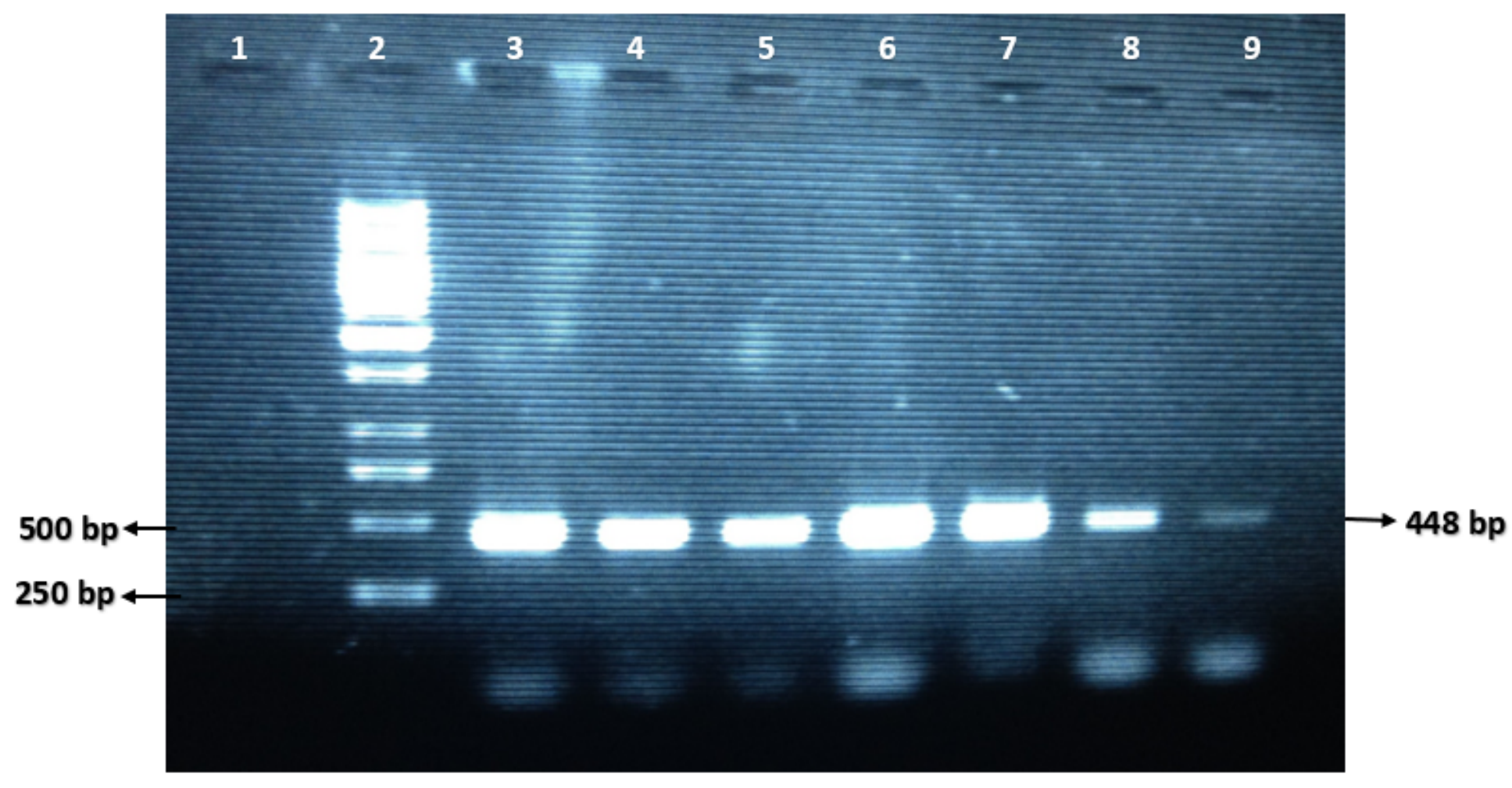

Figure 9

PCR products derived from 10 fold serial dilutions from 10-1-10-6 of Brucella spp. DNA and IS7II primers by $1.2 \%$ agarose gel electrophoresis and ethidium bromide staining.. Lanes: 1, E. coli as negative control; 2, $1 \mathrm{~kb}$ ladder (MBI-Fermentas); 3, positive control (B. melitensis); 4-9, diluted DNA from 10-1-10-6. 